\title{
Motivating Community College Students When Teaching Argumentative Rhetorical Style Using a Documentary: Devil's Playground ${ }^{*}$
}

\author{
Deniz Gokcora \\ Borough of Manhattan Community College-CUNY, New York, U.S.A.
}

\begin{abstract}
Competence in academic writing in college is a challenging as well as an engaging task for many college students. Argumentative writing and acknowledging the counterargument is one of modes that is introduced in freshman classes; however, college students approach writing with a certain mindset. Learning to write in different modes could be exciting when taught utilizing a film or a documentary. Using a documentary, such as Devil's Playground, writing professors not only initiate interest in culture learning and cultural understanding but also motivate students to use argumentation to foster critical thinking as well as cultural understanding.

Keywords: college writing, argumentative writing, argumentative reasoning, teaching counterargument, fostering culture learning, critical thinking, teaching through film, Devil's Playground
\end{abstract}

Teaching writing requires not only being able to write well, but it also demands that writing instructors be able teach how to write in different genres of writing, such as compare/contrast, description, narrative, or argumentation and similar modes of writing (Duke, Caughlan, Juzwik, \& Martin, 2012). Instructors need to understand the developmental stages of academic writing; in other words, they are most probably aware of the fact that students tell what they know about a subject matter first, and more advanced writers emphasize brainstorming, planning, writing, revising techniques (Harris, Santangelo, \& Graham, 2008).

Experienced writing instructors are keen on including the needs of students coming from diverse backgrounds; there are native speakers as well as nonnative speaker of English learners in writing classes. While international students might bring cultural richness into the classroom, they might have slightly different writing needs (Ortmeier-Hooper, 2013; Valdés, 1999).

Community colleges represent a global village, encompassing many cultures. Freshman writing classes at U.S. colleges include students from diverse backgrounds. Some of these students are immigrants with multilingual enclaves, such as Puerto Rico (Roberge, Siegal, \& Harklau, 2009). They join the academic world with a variety of academic competence, but mostly in need of academic critical reading and writing skills. This specific population is usually referred as Generation 1.5, and their writing challenges became the research topic of many studies (Harklau, Losey, \& Siegal, 1999; Singhal, 2004; Benesch, 2008; Roberge, Siegal, \& Harklau,

\footnotetext{
* Acknowledgement: The four questions and the argumentative prompt on Devil's Playground have been created by Amanda Millard.

Deniz Gokcora, Assistant Professor in ESL, Department of Academic Literacy and Linguistics, Borough of Manhattan Community College.
} 
2009; Bunch \& Kibler, 2015). Although they are nonnative speakers of English, they are mostly educated in the U.S., and they constitute a big population in writing classes (Matsuda, Saenkhum, \& Accardi, 2013). Academic competence is a stage in college that explores how students learn acquired skills for educational attainment. Both English as a Second Language (ESL) students and other native speakers of English have immediate needs and have some anxiety about or fear of enrolling in remedial English classes (Holland, 2013, Bunch \& Kibler, 2015). Irrespective of historical division, first-year writing courses in U.S. higher education and L2 writing have much in common in terms of student needs and academic preparation (Matsuda et al., 2013).

It is the responsibility of the instructor to foster respect towards different backgrounds and cultural pluralism. Acknowledging other life styles and cultural perspectives with reading, discussion, and reflection enables students to have better understanding about other cultures, life styles and religions. The faculty should be skilled and prepared to implement such curriculum transformations. In establishing global perspectives, students need to reflect on their background and understand the interaction of race, policies, customs, and opportunities provided in real life.

A survey (Matsuda et al., 2013) conducted to understand the perceptions of college writing professors' perceptions of their students reveals that composition instructors acknowledge the needs of L2 writers, and these instructors are enthusiastic about their students' need. These instructors, however, often do not make any special preparations to teach L2 learners, and program policies and the lack of teaching and assessment materials makes it difficult to teach professionally. The conclusion is that better understanding of both teacher and student needs is required.

\section{Culture, Technology and the Increasing need for Cross Cultural Understanding}

Culture is defined as "Shared assumptions, values and beliefs of a group of people which result in characteristic behavior" (Storti, 1998, p. 6). One's cultural identity is formed by multiple entities in life. There are different models of culture, and one of them is the three layer culture model suggested by G. H. Hofstede and G. Hofstede (2001).

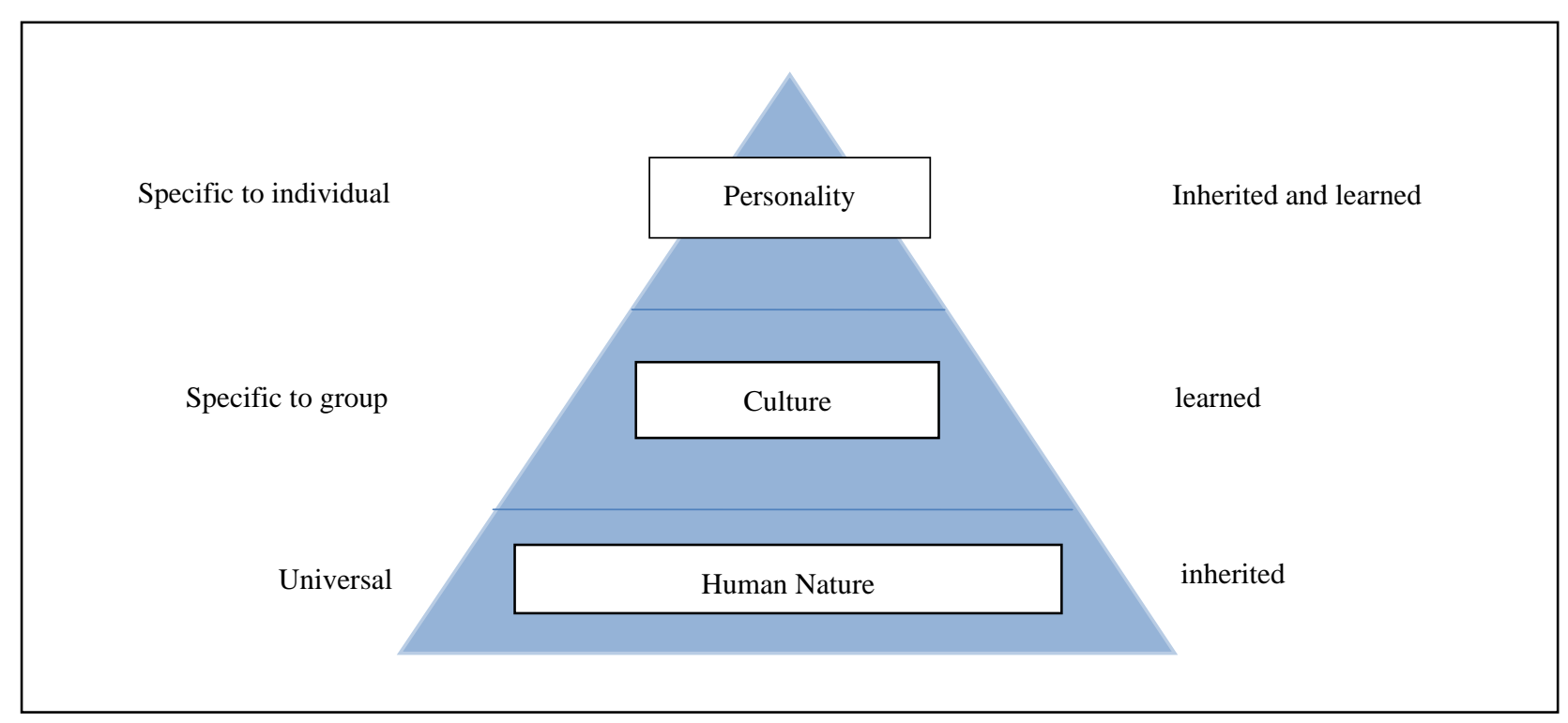

Figure 1. Layers of culture. 
Figure 1 shows the difference between human nature, culture, and personality in Hofstede's layers of culture paradigm. The bottom layer encompasses the elements of human nature: eating, sleeping, feeling different emotions (such as anger and love), which are universal. The middle layer is culture and includes religion, nationality, society, and race. The top layer is the personal level as every individual has his/her own culture irrespective of the greater culture in which the person lives.

Another model is the iceberg model of culture (The Cultural Iceberg). Like an iceberg, culture has two components: the visible and the invisible part. The visible part consists of the observable parts of culture, such as food, art, architecture, clothes, and behavior. Since these aspects of culture can be observed, people form opinions and ideas about their own and other cultures. Philosophy, the meaning of words, the meaning of behavior, the way people introduce themselves in public or address an elderly person are an unobservable part of culture. Each culture has its unique elements of the unobservable part of culture. For example, a Swiss national would appreciate a comment that an individual from an African culture might not interpret in the same manner. American undergraduates need to establish a mindset that would enable them to think that when speaking with someone from another culture, for example, an Italian, they need to have an understanding that the Italian has a different cultural background, and values, and basically a different way of thinking. Students need to understand that cross-cultural communication is essential for their own personal growth. They need to come to the realization that "partners' culture is one of many cultures in the world" and learn to establish a non-judgmental attitude to various cultures.

Today's American undergraduates seem to be more practical than in the past. However, they are much less willing to take risks and learn about other cultures. As stated by Levine and Dean (2012), "They're willing to have a major they're not really interested in if they think there will be job growth in that field. They're much less likely than their predecessors to say they're in college to develop their personal values, or learn to get along with different people". Irrespective of the many educational opportunities available to them, they are not ready to enter the world with a critical mind. They want to believe in the American dream, but they are insecure about their future due to dramatic changes in the economy. While they want to live in the Internet world and are connected to the digital world, they know very little about how to connect to people face-to-face. Levine and Dean (2012) believe that "This is a generation that thinks of itself as global citizens but knows little about the world and acts locally. It is the most diverse generation in collegiate history with the strongest relationship with races, but they have limited interest talking about race and reaching across political and generational divides” (p. preface).

They are digital natives, but they "have little knowledge about the world". Although these students come from diverse backgrounds, American undergraduates do not know much about the world around them. The result is an increasing push to internationalize the curriculum and pay attention to the growing need for global competencies in most academic subjects offered at colleges.

Considering American undergraduates in this light, there is a great need to include cultural topics in reading and writing classes. To do this might be curriculum challenge, but it is one with many positive aspects. It is essential that college students learn to how to establish a critical perspective in their argumentation. Both ESL and native speakers learn different rhetorical styles in remedial writing or ENG 101 classes. It is essential that students learn to bring a critical perspective to the topics discussed. Acknowledging the opposite point of view verifies that writers can practice argumentation and culture learning provides a very rich environment to practice argumentative writing style. 
The documentary, Devil's Playground (Walker, 2002), can be used as an example to teach about an ethnographic study of a subculture in the United States: The Amish way of life that is secluded and presents many aspects that are unknown to outsiders—be they American or foreign born.

Devil's Playground is a documentary about Amish teenagers and a critical choice they need to make during Rumspringa. At the age 16, Amish teenagers need to make a choice between adopting Amish tradition by joining the church or abandoning their traditional ways and accepting the American lifestyle. The documentary follows a number of Amish teenagers as they make this choice. They need to live by the rules of the Amish society and it is very difficult for them to leave the Amish tradition. Some of them, however, try to experience the "English world" and experience drinking, smoking, and drugs. Faron is one of these teenagers. He becomes a drug dealer to support his addiction after leaving Amish society. Velda, although baptized in the church, leaves the Amish society and is avoided (shunned) by her family upon her decision. According to the documentary, however, around $90 \%$ of teenagers choose to remain in the Amish society and live a religious life after they go through Rumspringa (Walker, 2002).

\section{Starting the Argumentation-counter Argument Module}

This module includes a series of activities that would be useful to gather information and practice skills to compose an argumentative paper based on Devil's Playground. Students need to make an argument in the context of a counterargument. College students in different disciplines learn the writing conventions in their own majors, and there is no "discipline that does not require writers to frame their own claims as a response to what others before them have said” (Birkenstein \& Graff, 2006, p. XVIII). Counter argument is framed as an argument that opposes the writer's point of view. Skillful writers, when making an argument, also map out those claims that are opposite to those that they make, which are known as "they say" claims. Acknowledging the other point of view, in other words, the counterargument identifies the writer as an informed researcher. The other side's perspective can be acknowledged using phrases as "I hear that you're saying X and I understand, but the reality/my perspective is $\mathrm{Y}$ and here are the reasons for it". Students need to be aware of the strengths and weakness of other writers' ideas.

These are the steps that lead to an argumentative essay writing using Devil's Playground:

(1) The unit starts with a Beatles song-Imagine There is no Heaven that provides a context every student might be interested in. As this is a song about world peace, it can resonate with many international students. One sentence in the lyrics especially is singled out as it is about imagining a place/country where "nothing to kill or die for". The instructor discusses the meaning of this song and how it promotes world peace.

(2) Then students learn to engage in argumentative discussion using a three-column outline format, including reasons to support their point of view, the opposing point of view (counter argument) and the rebuttal (refuting the counterargument). The instructor gives them a prompt such as: There is nothing worth dying for. Country, family, not even religion. This idea is shown in Table 1.

Thesis: There is nothing worth dying for. Country, family, not even religion is worth it dying for.

The instructor and students together generate ideas and examples from current events or events in the past and fill out the chart. For example, there are many countries that are in conflict with other countries and at war, and the instructor could give examples from those areas of conflict and point out that wars stimulate more wars. The opposite point of view can indicate that independence needs to be established even if there need to be wars between countries. The reason for not living a life of a religious person could be that people abide by their own 
rules and do not need religion anymore since this is the 21st century and individualism counts more than religious conformity. This exercise provides an opportunity for students to understand counter argument and rebuttal.

Table 1

Table of Argumentation

\begin{tabular}{|l|l|l|}
\hline My point of view (the writer's reasons) & $\begin{array}{l}\text { The opponent's point of view } \\
\text { (counterargument) }\end{array}$ & $\begin{array}{l}\text { Rebuttal (writer's answer to the } \\
\text { counterargument) }\end{array}$ \\
\hline $\begin{array}{l}\text { Country: reasons for the fact that it is not } \\
\text { worth dying for one's country }\end{array}$ & & \\
\hline $\begin{array}{l}\text { Family: } \\
\text { Religion: }\end{array}$ & & \\
\hline
\end{tabular}

(3) Argumentative research-based essay: The instructor introduces a technology topic-for example, the Internet as students are interested in computers, texting, searching information online, cell phones. Nicholas Carr's Is Google Making Us Stupid? (2008) essay discusses how the overuse of the Internet and computers affects our thinking process. He gives examples from his own life and indicates that he cannot concentrate when he wants to read a lengthy article or a book. He has difficulty getting back to the reading activity. Using the Internet, Google actually has changed how people think and possibly the nature of the human brain.

Another essay on the same topic is James Casio's Get Smarter. As a futurologist, Casio makes the argument that human beings have survived since the beginning of civilizations due to their persistence and by adapting to the needs of their environment. He believes that human brain evolved by overcoming problems; in other words, as people got smarter, they were able to survive the difficulties and advanced civilization through technological innovations. The Internet is one of the innovations that has helped human beings overcome many problems.

These two articles provide students with two different perspectives on the use of technology and the Internet. As they start working on the argumentative paper, they need to be able to get engaged in academic discussion and can do so by using the three-column argumentation chart including a counterargument and a rebuttal. Students are required to find related articles from library databases that would help them to construct their own argument on the topic. After sharing their research paper with each other, students revise the paper to submit it to the instructor.

(4) After discussing the technology topic, students are asked to imagine that there was no technology. A world without technology might have consequences that they might not imagine.

(a) Film viewing and writing an argumentative paper on Devil's Playground. After viewing the documentary, the class discusses the documentary using questions, such as,

The following:

- A caption in the film states the following: "The Amish allow a Rumspringa tradition known as 'bed courtship'. At the end of a date, an Amish boy is allowed to share the Amish girl's bed for the night”. Parents just assume that the young couple will become intimate, and many girls in fact become pregnant. Is there anything religiously contradictory about "bed courtship", and is this a practice that the rest of society might benefit from?

- Why do you think an amazingly high percentage of Amish children return to their culture to be baptized after they have lived in the outside world? What challenges are mounted against those few who decide not to return?

- Do you think that the ritual of Rumspringa is a benefit to these children, or a cruel way of introducing the outside world? On one hand, the choice to accept or deny this religion is obviously left up to them (where other religions often feel forced upon people); on the other hand, these kids fall into trouble (drugs, etc.) because of their sheltered upbringing. 
- Put yourself in the shoes of one of the Amish kids profiled. You will undoubtedly see the obvious downside to their way of life compared to your own (no electricity, no modern conveniences), but what are the benefits of this type of culture? How could your own community be strengthened by adopting some of the Amish practices? (Amanda Millard, Personal Communication, November, 2011).

The following is an answer provided to the Question \# 2-The challenges waiting for Amish teenagers:

The modern English world is too advanced for Amish people. Too muchsensation and too much temptation are there. Outside world has lots of challenges that everybody has to face, while Amish people are hard worker. Their lives are simple. They are working hard, but they do not have stress in their lives. They are religiously bound to the God. Their religion keeps them together, so one can find the support from friends and families. That is why the high percentage of Amish children return to their culture to be baptized after they have lived in the outside world.

Transition to the debate and the argumentative paper:

(b) After these questions are discussed, the following topic is given to students for a class debate, and it enables students to establish their personal point of view on the topic.

(c) A caption in the film states the following: "Believing that education leads to pride, the Amish require their children to drop out after 8th grade and being working”. The formal education they do receive is from one-room Amish schoolhouses. Because of this, the Amish typically work in manual trades, and those who leave the Amish church are ill-equipped to obtain much better than factory jobs. Should the U.S. government step in and force the Amish to better educate their children?

In their argumentative essay, students need to provide counter arguments and provide a rebuttal as they learned. They need access the weaknesses and strengths of opponents' viewpoints as well as theirs. The debate prepares students to write the argumentative paper.

The following is an example from a student paper. The writer first makes a plan of what is going to go in the paper.

Table 2

Table of Argumentation for Devil's Playground

\begin{tabular}{|l|l|l|}
\hline Writer's reasons & Counter argument & Rebuttal \\
\hline $\begin{array}{l}\text { The Amish community is a free, } \\
\text { independent entity in the U.S. They need to } \\
\text { be able to practice their own beliefs and } \\
\text { values in their community. }\end{array}$ & $\begin{array}{l}\text { I agree with the idea of First Amendment; } \\
\text { however, if they want to be independent } \\
\text { and rely on themselves, they need to be } \\
\text { self-sufficient and not dependent on the } \\
\text { greater society, so providing more } \\
\text { opportunity for education will help them to } \\
\text { do so. Education is the only way to be } \\
\text { competitive. }\end{array}$ & $\begin{array}{l}\text { They don't need any competition, and they } \\
\text { communities for a society that is away } \\
\text { from the evils of social destruction. }\end{array}$ \\
\hline
\end{tabular}

An example introparagraph:

Of course, believing in religion does not give us easy, advanced, and professional life, but it surely ensures the way to the heaven. There are lots of religions in this world, and they all have diversity and specialty in terms of rules and regulation. Amish people and their sophistication are totally unique among them. Since Amish people are living in the USA, government should not interrupt to them and their beliefs. It is true that education leads to the success with prospect in the life, yet Amish culture object the pride, success, and prosperity. Amish community, however, could be strengthened through public education. According to their 
beliefs and motto of living lives, government should not step in and force the Amish to better educate their children because everyone has a freedom of choice in the USA, Amish people are religiously bound to the strict community, and in today's time there are too much temptation, competition, challenges exist in this modern world.

Another paragraph describes one of the reasons that the writer supports a religious life style, providing some evidence from the documentary. This paragraph is followed by a counterargument as in the following example:

Thesis: According to their beliefs and motto of living lives, government should not step in and force the Amish to better educate their children because everyone has a freedom of choice in the USA, Amish people are religiously bound to the strict community, and in today's time there are too much temptation, competition, challenges exist in this modern world.

Explaining an argument and a counter argument:

According to their beliefs and motto of living lives, government should not step in and force the Amish to better educate their children because everyone has a freedom of choice in the USA, Amish people are religiously bound to the strict community, and in today's time there are too much temptation, competition, challenges exist in this modern world.

Counterargument and a rebuttal part:

Opponents of religious beliefs and myths state that higher education is not hurting any societies, or any religious community. Education does not interrupt their religion. Education gives them opportunity to enhance their living style through miscellaneous internet and technological tools. Here they are missing the point that Amish people are religiously bound to their very strict community. Since they believe that education leads to the pride, Amish people drop out from the school at the 8th grade. With the respect to their religion, Amish children help their parents in the farm or any small furniture business. They do not need to study hard if their goal is to working hard in the fields.

Significance of teaching argumentation through teaching critical thinking and cultural competency skills:

Integrating global issues, such as race, ethnicity, and different religious orientation challenge students to think about their identity, society and history in a broader and a more complex way. They need to be able to see the interconnectedness of their lives with current events happening in life. As they put their thoughts in writing, they gain confidence in their critical writing and self-expression skills and stand up for their beliefs and challenge the already established ideas in society.

It is important to enhance critical thinking skills through teaching the argumentative rhetorical style. Many students in American higher education system do not acquire the necessary critical thinking skills (Smith \& Szymanski, 2013) and do not have a realistic understanding of what these skills are (Rowles, Morgan, Burns, \& Merchant, 2013; Choy \& Cheah, 2009; Henderson Hurley \& Hurley, 2013). Learners, especially ESL students benefit from these lessons in learning and using new vocabulary related to the new content area. For example, they get familiar with new words, such as Rumspringa, shunning; in the technology topic: information overload.

Not only students are learning new content but they are also motivated to read and write on a new topic. Reading and writing on a new topic motivates them to collaborate and co-construct new knowledge. There is an effective transfer of cultural knowledge for writing and for other courses they take besides English. As they become aware of other cultures and worlds, their understanding of the world helps them to create more 
meaningful relationships with greater issues in life. For example, they have a better understanding of unpredictable events in life and face challenges in a competent manner. Kramsch (2004) advocates the idea that as they learn about other cultures, they are most likely to face challenges in life. Through integrated reasoning, students find ways for discussion, reflection, and meaningful feedback. They need to understand the dynamics between history, immigration, culture, economics, and sociopolitical interplay of events in their background and what makes them who they are today.

\section{References}

Benesch, S. (2008). “Generation 1.5” and its discourses of partiality: A critical analysis. Journal of Language, Identity, and Education, 7(3-4), 294-311.

Bunch, G. C., \& Kibler, A. K. (2015). Integrating language, literacy, and academic development: Alternatives to traditional English as a second language and remedial English for language minority students in community colleges. Community College Journal of Research and Practice, 39(1), 20-33.

Carr, N. (2008). Is Google making us stupid?: What the Internet is doing to our brains. Retrieved from http://www.theatlantic.com/magazine/archive/2008/07/is-google-making-us-stupid/306868/

Choy, S. C., \& Cheah, P. K. (2009). Teacher perceptions of critical thinking among students and its influence on higher education. International Journal of Teaching and Learning in Higher Education, 20(2), 198-206.

Duke, N. K., Caughlan, S., Juzwik, M. M., \& Martin, N. M. (2012). Reading and writing genre with purpose in K-8 Classrooms. Portsmouth, NH: Heinemann.

Graff, G., \& Birkenstein, C. (2010). They say/I say: The moves that matter in academic writing. New York: W.W. Norton \& Co.

Harklau, L., Losey, K., \& Siegel, M. (1999). Generation 1.5 meets college composition: Issues in the teaching of writing to U.S. -Educated learners of ESL. Mahwah, NJ: Earlbaum.

Harris, K., Santangelo, T., \& Graham, S. (2008). Self-regulated strategy development in writing: going beyond NLEs to a more balanced approach. Instructional Science, 36(5-6), 395-408.

Henderson Hurley, M., \& Hurley, D. (2013). Enhancing critical thinking skills among Authoritarian students. International Journal of Teaching and Learning in Higher Education, 25(2), 248-261.

Hofstede, G. H., \& Hofstede, G. (2001). Culture's consequences: Comparing values, behaviors, institutions and organizations across nations. Thousand Oaks CA: Sage.

Holland, R. (2013). Writing experiences of community college students with self-reported writing anxieties and linguistic insecurity: A perspective for college counselors. Community College Journal of Research and Practice, 37(4), 278-295.

Kibler, A. K., Walqui, A., \& Bunch, G. C. (2015). Transformational opportunities: Language and literacy instruction for English language learners in the Common Core era in the United States. TESOL Journal, 6(1), 9-35.

Kramsch, C. (2004). The multilingual experience: Insights from language memoirs. Retrieved from http://escholarship.org/uc/item/9h79g172

Levine, A., \& Dean, D. R. (2012). Generation on a tightrope: A portrait of today's college student. San Francisco, CA: John Wiley \& Sons.

Matsuda, P. K., Saenkhum, T., \& Accardi, S. (2013). Writing teachers' perceptions of the presence and needs of second language writers: An institutional case study. Journal of Second Language Writing, 22(1), 68-86.

Ortmeier-Hooper, C. (2013). The ELL writer: Moving beyond basics in the secondary classroom. New York: Teacher's College Press.

Roberge, M., Siegal, M., \& Harklau, L. (2009). Generation 1.5 in college composition: Teaching academic writing to US-educated learners of ESL. New York: Routledge.

Rowles, J., Morgan, C. M., Burns, S., \& Merchant, C. (2013). Faculty perceptions of critical thinking at a health sciences university. Journal of the Scholarship of Teaching and Learning, 13(4), 21-35.

Singhal, M. (2004). Academic writing and generation 1.5: Pedagogical goals and instructional issues in the college composition classroom. The Reading Matrix, 4(3), 1-13.

Smith, V. G., \& Szymanski, A. (2013). Critical thinking: More than test scores. International Journal of Educational Leadership Preparation, 8(2), 15-24.

Storti, C. (1998). Figuring foreigners out: A practical guide. Yarmouth, ME: Intercultural Press. 
The Cultural Iceberg. Language and Culture Worldwide, $2015 . \quad$ (2015). Retrieved from http://languageandculture.com/cultural-iceberg

Valdés, G. (1999). Incipient bilingualism and the development of English language writing abilities in the secondary school. In C. J. Faltis, \& P. M. Wolfe (Eds.), So much to say: Adolescents, bilingualism, and ESL in the secondary school (pp. 138-175). Walker, L. (2002). Devil's Playground (documentary film). 